\title{
《)
}

\section{GRUPO DE ESTUDOS DE PINTURA APOTHEKE ESCRITOS SOBRE A EXPERIÊNCIA}

Marta Facco

Todos nós, enquanto seres humanos, possuímos experiências, porque nos relacionamos e interagimos com as pessoas e o ambiente onde nos inserimos. Vivenciamos sensações, emoções, momentos e acontecimentos, que muitas vezes causam marcas verdadeiramente duradouras e, quem sabe, eternas. Instantes que são capazes de mudar o sentido de tudo, do modo como enxergamos o mundo, os outros e até os objetos ao nosso redor. São capazes de trazerem significações tamanhas que suportam abrirem recortes na paisagem da memória, congelarem o tempo por instantes, e nos avassalarem - presente. Muitas vezes essas experiências reais apenas passam pelo caminho da experimentação e/ou experiências vividas, sem a consciência, percepção e acepção do ato, porque todos os dias vivemos experiências reais, de carácter rítmico particular e de qualidades diferenciadas para cada um, pois somos seres únicos.

A contraponto a todas essas experiência ditas reais, está a 'experiência singular' citada por John Dewey, que é única e impossível de ser vivida e sentida igualmente por outra pessoa que se submeta a fazer o mesmo processo, pois sempre será diferente para cada um. Em uma experiência singular o fluxo sempre irá de algo para algo, assim sempre teremos um começo e um fim, onde a conclusão é uma consumação e nunca uma cessação, e o percurso é o ponto mais importante desta experiência.

Vejamos: se a experiência é o que nos acontece, nos atravessa e nos toca, nós somos o território de passagem ou o espaço onde os acontecimentos se sucedem. Assim, para 


\section{A) APOTHEKE}

tornarmos esses acontecimentos experiências ímpares, precisamos estar abertos e suscetíveis ao desconhecido, ao novo, ao perigo, e conscientes das circunstâncias que nos interferem. Precisamos perceber compreender e interpretar o efeito deste contato epistêmico direto e suas potências. Digamos que seria olhar sobre o ponto de vista do corpo vibrátil, o que nos acontece entre o mundo e o corpo.

Durante a experiência singular, não há vazios de acontecimentos, buracos, fendas ou mesmo cessamentos, pois isso não acontece dentro do corpo vibrátil, o que ocorre são pausas, lugares de repousos, respiros, intervalos que auxiliam na pontuação e definição da qualidade do movimento; pois a aceleração contínua impediria a distinção entre as partes.

Atendo-me um pouco mais ao intervalo onde todo o processo ocorre, entre o começo e o fim, especulo sobre o que seria uma experiência estética, ou melhor, uma experiência com qualidade estética, que para as artes em geral é o diferencial para um possível trabalho artístico de qualidade. $\mathrm{Na}$ experiência do pensar tem sua própria qualidade estética e se difere das outras experiências por ser construída de palavras, porque somos construídos de palavras e pensamos com palavras. Palavras produzem sentidos, criam realidades, dão sentido ao que somos e ao que nos acontece, e às vezes, funcionam como potentes mecanismos de subjetivação. Mesmo assim, apenas manifestam-se no âmbito do pensar, podendo ter conclusões intelectuais por si só, que consistem em sinais e símbolos sem qualidade intrínseca própria, mas que podem ser qualitativamente vivenciadas. Já a experiência estética criase da percepção, interpretação e compreensão dos acontecimentos que vão surgindo durante o processo e o cuidado que se tem com essas informações, condições essas, que tem papel fundamental atingir o corpo vibrátil. 


\section{X|}

Mas o que move uma experiência artística? Arrisco-me em mencionar a 'falta'. Essa busca incessante pelo desejo movida pelas emoções e afetividades armazenadas no corpo vibrátil, pois quando significativas, são qualidades importantes de uma experiência complexa e singular. As emoções não fazem parte da regra para ter-se uma experiência estética, mas podem ser um dispositivo propulsor para que se tenha uma experiência verdadeiramente significativa. Lembro-me claramente a primeira vez em que estive no Masp (Museu de Arte de São Paulo) em 1997. Era apenas uma estudante de graduação, estava ainda tentando entender o mundo fabuloso das Artes, quando me deparei com a obra Impressionista do pintor francês claude Monet "Canoa sobre o Epte" de 1890. Já tinha visto dezenas de vezes nos livros, mas até então, nunca havia sentido qualquer interesse por ela. Quando parei em sua frente fiquei hipnotizada, meu coração disparou e minhas mãos começaram a suar, como se a paixão tivesse me arrebatado naquele instante. Percebia o movimento das pessoas passando ao meu redor, mas eu estava imóvel. Naquele instante o tempo estagnou-se e um turbilhão de emoções me invadiu sem pedir licença para entrar. Olhei a minha volta e percebi que somente eu estava vendo aquilo tudo. A canoa deslizava sobre - rio, enquanto duas damas conversavam e riam. A brisa teimava em sacudir as plantas ali presentes e eu podia sentir ao frio que acontecia naquele instante da cena. Sentia-me mergulhada dentro dela. Cada cor, cada pincelada ali colocada se ligava a algo dentro de mim que não sabia explicar, apenas sentir. Acredito que uma experiência singular precisa ser movida pelo corpo vibrátil, e que a partir deste instante terá qualidades para desenvolver-se em uma experiência estética, que não será uma regra.

o que faz uma experiência ser uma experiência em arte é a união da relação e percepção entre o agir e o sofrer, entre a 


\section{《I}

energia de saída e a de entrada, entre o fazer e estar sujeito a algo. A experiência do ato estético tem haver com consciência e está ligada ao seu sentido estrito à experiência de criar, apoiando-se em proporções e equilíbrios, controlados por um senso refinado das relações entre o mundo e o corpo vibrátil. Portanto, uma experiência com qualidade estética será um trabalho realizado com relações qualitativas da percepção, compreensão e interpretação do material recolhido durante o processo de uma experiência singular significativa. Todos os acontecimentos advindos dessa experiência que interferem na matéria do corpo vibrátil causam relações profundas de identificação com um trabalho criativo em arte.

Assim, vivenciar experiências, faz parte do estar vivo e sujeito a algo. Sejam elas experiências reais, singulares, intelectuais ou estéticas elas serão sempre importantes para proporcionarem ritmo e unidade ao trabalho, protegendo-o da monotonia e da repetição. Sua sucessão é pontuada pela existência de intervalos que determinam a cessação de uma fase e o início de outra, e também lapida o trabalho em construção.

BIBLIOGRAFIA:

DEWEY, John; Arte como experiência; tradução Vera Ribeiro; São Paulo: Martins Martins Fonte, 2010. (p 109-141)

BONDÍA, Jorge Larrosa; Tremores: escritos sobre experiência; tradução Cristina Antunes, João Wanderley Geraldi- $1^{a}$. ed., $1^{a}$ reimp.- Belo Horizonte: Autêntica Editora, 2015. (p15-43)

\section{Marta Facco}

http: / / lattes.cnpq.br/7820911643666261

ISSN: 2447-1267 Santa Catarina, v.2, n.2, ano 2, fevereiro de 2016. 